\title{
Agroecological practices to support tropical livestock farming systems: a Caribbean and Latin American perspective
}

- Gisele Alexandre,

- Lylian Rodriguez,

- Javier Arece,

- José Delgadillo

- Gary Wayne Garcia,

- Kurt Habermeier,

- André M. Almeida,

- Audrey Fanchone,

- Jean-Luc Gourdine \&

- Harry Archimède

Tropical Animal Health and Production volume 53, Article number: 111 (2021) Cite this article

- $\mathbf{4 8 0}$ Accesses

- 1 Citations

- Metricsdetails

\section{Abstract}

With global climate changes currently occurring, and particularly given the severe energy and food shortages occurring throughout tropical regions, agroecological (AE) systems are drawing renewed attention as an efficient alternative to intensive models of production, particularly unsuitable in regions of the world such as the Caribbean or Latin America. There is a pressing need to focus on livestock farming systems (LFS) and characterize their potential contributions to global sustainability. A multidisciplinary approach is needed to address these multiple and complex problems.

Traditionally, LFS have shown their sustainability high potential. The purpose of this work is to highlight solutions to minimize inputs, by describing some success and diverse case studies through the Caribbean. These systems were analyzed at different levels: animal/function, farm/family, and territory/society. This produced a set of guidelines that help to increase the efficiency of tropical systems, particularly those concerned with (1) choosing 
the best-suited genotypes, while enhancing population biodiversity; (2) matching the farming system to the available resources, feed, and byproducts; (3) steering the whole farming system through reproduction management with no hormonal treatment, while facilitating system reproducibility and increasing performances; (4) controlling health constraints instead of annihilating risks and implement an integrated management design to reduce chemical treatments or increase the use of nutraceuticals; and (5) mitigating climate constraints by using soft techniques. In the second part of this work, some integrated systems are described. The Tosoly farm of Colombia, for instance, is conceived as a totally integrated crop-livestock system, allowing the additional production of energy at the farm level. Thus, it epitomizes the positive impact that livestock can exert upon the environment. The case study of Haiti indicates how AE practices can help in designing a pro-poor sustainable milk production system. It concerns an entire dairy sector built all over the country on the basis of micro-units of milk production and processing.

Access provided by Universidade de Lisboa, member of B-on Consortium Portugal

\section{Introduction}

Given the present and anticipated climate, energy, and economic changing situations, the concept of agroecology (AE) (Gliessman 2006; Wezel et al. 2009) became one of the most robust pathways to attain sustainable development (including all three dimensions of sustainability, technical, socioeconomic, and environmental). There is a pressing need to focus on livestock farming systems (LFS) to describe and quantify their potential contributions, either positive or negative, to sustainability. This will be especially significant in developing countries that are interested in being food (Altieri et al. 2012) and fuel (Preston and Rodríguez 2014) self-sufficient. Particularly, given the projections for human population growth in tropical regions, it is necessary to increase the availability of high-value animal protein foods produced locally, namely, meat and dairy products (Faye et al. 2011; Hernández-Castellano et al. 2019). However, new questions arise with regard to sustainability issues.

Dumont et al. (2013), prospecting for the twenty-first century, stated that "surprisingly, animal farming systems have so far been ignored in most agroecological thinking." However, within the tropical developing world, and for a long time, studies have also been undertaken with a development focus, as detailed in Cuba (Funes-Monzote and Monzote 2001), Haiti 
(Habermeier 2003), and Brazil (Ahrens et al. 2009). Furthermore, the implications for the improvement in human well-being were identified in specific African nations like Guinea-Bissau (de Almeida and Cardoso 2008). Finally, Ahrens et al. (2009) have reviewed research carried out in Brazil from 2004 to 2009 under the protection of the "Agroecology Program" and have identified various animal production programs that could fit in this category. Altieri and Toledo (2011) described what they called the "agroecological revolution" in Latin America and indicated, among numerous case studies, those dealing with livestock, whether integrated or not in agroecosystems. Thus, agroecology, with its concept and practices, is a global concern involving agricultural and animal production (Gliessman 2006; Dumont et al. 2013).

Improving AE methods that would lead to both food security and biodiversity preservation must include the dissemination of ideas and practices (Wezel et al. 2009), especially considering issues that would be relevant to small farmers (Altieri 2002). This is because the majority of farms in many developing countries in Asia (Devendra 2007) or in tropical islands (Fanchone et al. 2020) are small-scale farmers. Dumont et al. (2013) went further than just modifying practices in the current LFS, by integrating the different practices from different agroecosystems. The concepts of LFS, including their social and biophysical dimensions, and of AE can be merged in order to design sustainable LFS, as shown, for instance, in the Caribbean region (Alexandre et al. 2014). Reviews of AE principles can be obtained in Altieri (2002), Gliessman (2006), and Dumont et al. (2013) and readers should consult them for further details.

The following sections will focus on different integrated systems. These are integrated at different levels such as biological function, herd management, or purpose of the system and include different case studies in the Caribbean and Latin American regions. This article details successful agroecological techniques implemented under specific animal production conditions on Caribbean and Latin American countries.

\section{General framework}

Animal performance depends on genetic potential, environmental conditions, and the interactions between them. Animal production results from complex and differing ecological processes. Considering the relevance of domestic animals in the food chain and the fact that a LFS can be defined as an open system (Dedieu et al. 2011), we must recognize that these systems are necessarily connected to a specific environment. As a result, they depend on the direct and indirect environmental effects, while in turn, they affect in 
different ways, the materials, soil, atmosphere and water, and consequently biomass production (Fig. 1). Thus, implementing AE practices should initially consider the ecological identity and agriculture potential of the environment. The characterization of animals and systems, as well as their different combined variation factors, must be carried out for the different animal traits and their contribution to production, through a holistic approach (Alexandre et al. 2014). Furthermore, it is necessary to consider both the genetic potential and the feeding, health status, and reproductive capacities (Alexandre et al. 2014; Fig. 1). In fact, a multidisciplinary approach is important and can function in an integrated fashion (Fig. 1).

\section{Fig. 1}




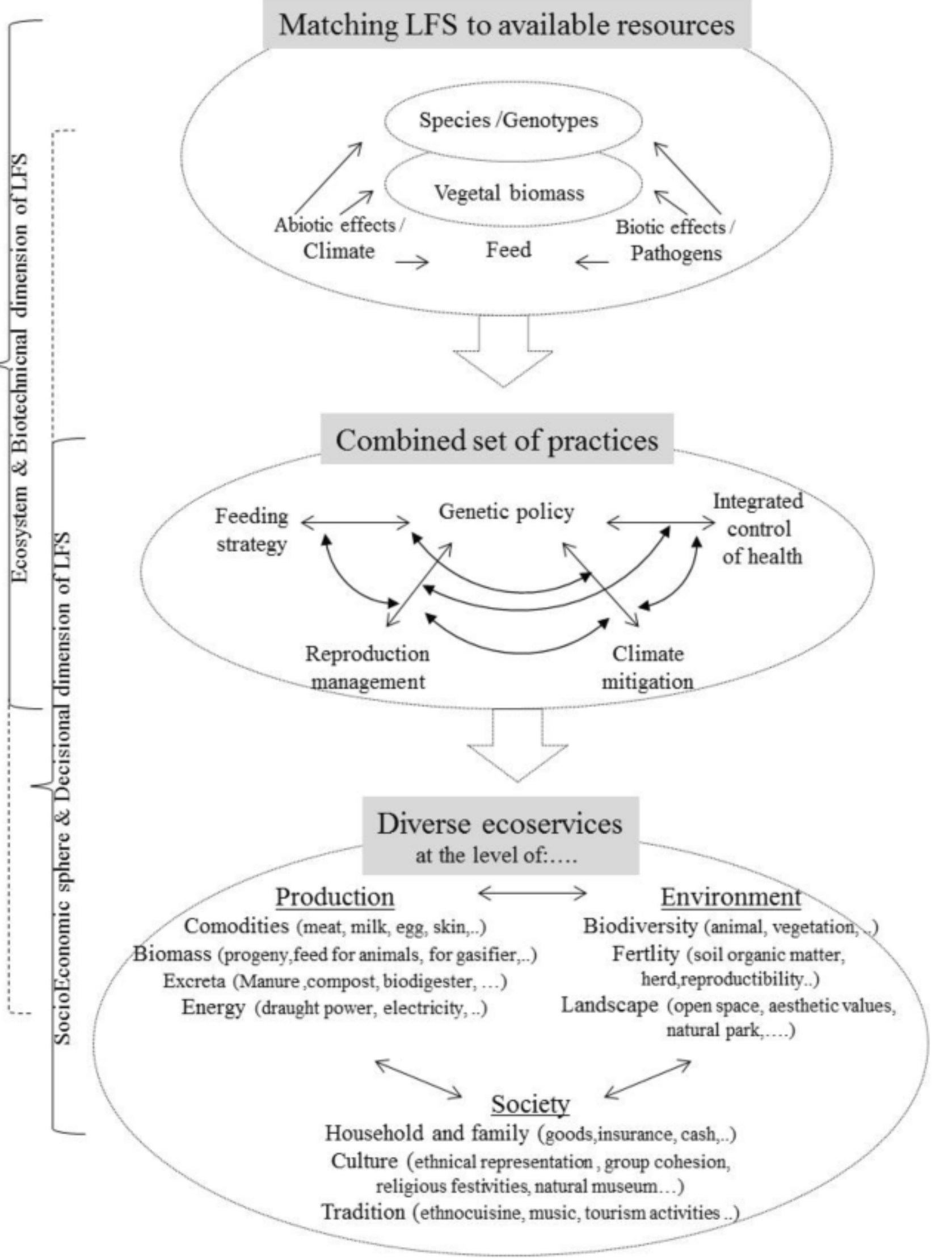


Main principles and practices for designing agroecological livestock farming system (LFS) in the Caribbean and provisioning of ecoservices

\section{Full size image}

Combinations of agroecological practices

The conceptualized combined sets of practices are (1) matching the resources and animal genotypes to the environment and (2) addressing the main environmental limits by integrated practices.

\section{Matching the resources and animal genotypes to the environment}

Environmental conditions have both direct effects via abiotic factors (i.e., climatic parameters) and indirect effects via biotic factors (i.e., level and quality of feed resources, presence of pathogens, and pathogenicity). Animal production is severely limited by heat stress. This implies that from an agroecological perspective, it is better to raise well-adapted species and genotypes (Wilson 2009; Hoffmann 2013) to such conditions, namely, the indigenous breeds living in the tropics (Naves et al. 2000; Magana et al. 2010; Preston and Rodríguez 2014). Thus, exotic species, especially those that were imported from tempered or developed countries, will require management systems with higher input requirements and necessarily higher costs. Regardless, breeds originating from other tropical nations may in some cases end up being very effective in comparable environments. For instance, the Damara and Dorper breeds of Southern Africa have adapted well to the arid conditions of Brazil and Australia (Almeida 2011; Scanlon et al. 2013). Also, the Canarian goats showing great adaptability to limited feed resources (Lérias et al. 2013; Palma et al. 2017) have been successfully exported to tropical countries (Venezuela, CaboVerde). These animals can be considered as useful alternatives. Indeed, Wilson (2009) advocated "choosing the right animal in the right place."

\section{Animal genetic resources}

Overall, animal productivity ultimately depends on numerous components such as genotype, environment, and husbandry factors. The low degree of current animal productivity in tropical locations is conventionally related to reduced genetic potential alongside with harsh environments. The production potential results from the impact of the environment on an animal that has adapted over the centuries to harmful pathological constraints (i.e., gastro intestinal or tick borne diseases) and nutritional deficiencies (i.e., reduced biomass due to drought, low $\mathrm{N}$ level of tropical forages). In these unfavorable 
contexts that an animal must face, it must rely on many physiological functions: immunity, reproduction, nutrition, lactation, and growth. The study of nutrient allocation (Friggens and Newbold 2007; Poullet et al. 2019) helps to understand the mechanisms of these intricated physiological responses. For instance, Alexandre et al. (2014) reported that in goats, the immune function takes priority over growth function. Some other examples are the Canarian goats that can be tolerant to weight loss during feeding restriction (Lérias et al. 2013; Palma et al. 2017). We should consider that higher potential for productive performances implies higher nutritional requirements and lower nutrient accessibility for the adaptive function. This often involves the purchase of external inputs and equipment that are costly and distant from $\mathrm{AE}$ principles.

The challenge for agroecological purposes (Fig. 1) is to achieve a balance between adaptations to the environment while implementing innovations to improve production. Producing while reducing negative effects on the environment must also ensure benefits for society. Very few tropical breeding programs are based on both adaptive and productive traits (Gunia et al. 2013). Nevertheless, other traits such as feeding efficiency or heat adaptation are gaining importance (Gourdine et al. 2013, 2019).

The key points are to choose well-adapted genotypes, to maintain their performances under many stress types, and to build breeding programs matched to the prevailing regional LFS. Following these AE principles will help to enhance general biodiversity while pursuing their resilience, as stated, for instance, in goats by Alexandre et al. (2010). Thus, the preservation and improvement of local well-adapted breeds is strategically important (Gourdine et al. 2013; Gunia et al. 2013). In the Caribbean, a good example of resilience and fitness is the Barbados Blackbelly ovine breed which has gradually adapted to the specific environmental conditions of the islands (Almeida 2018). Nevertheless, imports of exotic breeds with better performances should be considered carefully to avoid losses of local genetic resources such as those affecting several Creole breeds in various regions of Latin America (Martínez et al. 2012) or Southern Africa (Almeida 2011).

\section{Feeding strategies}

Feeding and nutrition-related factors interfere and often determine individual vulnerability to climate constraints or potential diseases. Feeding practices should match the accessible local resources (Fig. 1). Many authors have suggested that priority should be given to using all available feeds and coproducts rather than selecting only those with high nutrient density to 
maximize production performance. It is not yet a question of maximizing the biological function within the context of animal production, but instead of rationalizing the fractioning of food /feed resources at farm and land level, without competition between human and animal users. The challenge is to reach an equilibrium between production (i.e., family- or market-driven enterprise) and adaptation to the ecosystem conditions (i.e., supply-driven activities).

González-García et al. (2012) suggested that the Caribbean region is rich in fodder and unconventional resources that were not fully utilized. Archimède et al. (2014) featured various utilizations of resources in assessing various models: ligneous, glucidic, amylolytic, tanniferous, and protein-for monogastric animals and ruminants in Cuba, Colombia, Guadeloupe, and Trinidad (Table 1). Their different feeding values (Fig. 2), seasonal availability, and yield result in the possibility of providing mixed diets offered to different animal groups based on the requirements established by species, physiological status, purpose, etc. However, this feeding system can face several problems such as unbalanced diet, insufficient quantity, and variable labor time according to the diet. This will need further research on nutrient allocation, in the context of the genetic potential of the animals. This implies reconsidering other definitions of feed efficiency based not only in nutrient efficiency but also resource use efficiency and linking it to animal productivity.

Table 1 Some examples ( $x=$ existence of studies) of foliages and nonconventional feeds offered to goat or pig showing the high biodiversity of Latin America and the Caribbean

Full size table

Fig. 2 


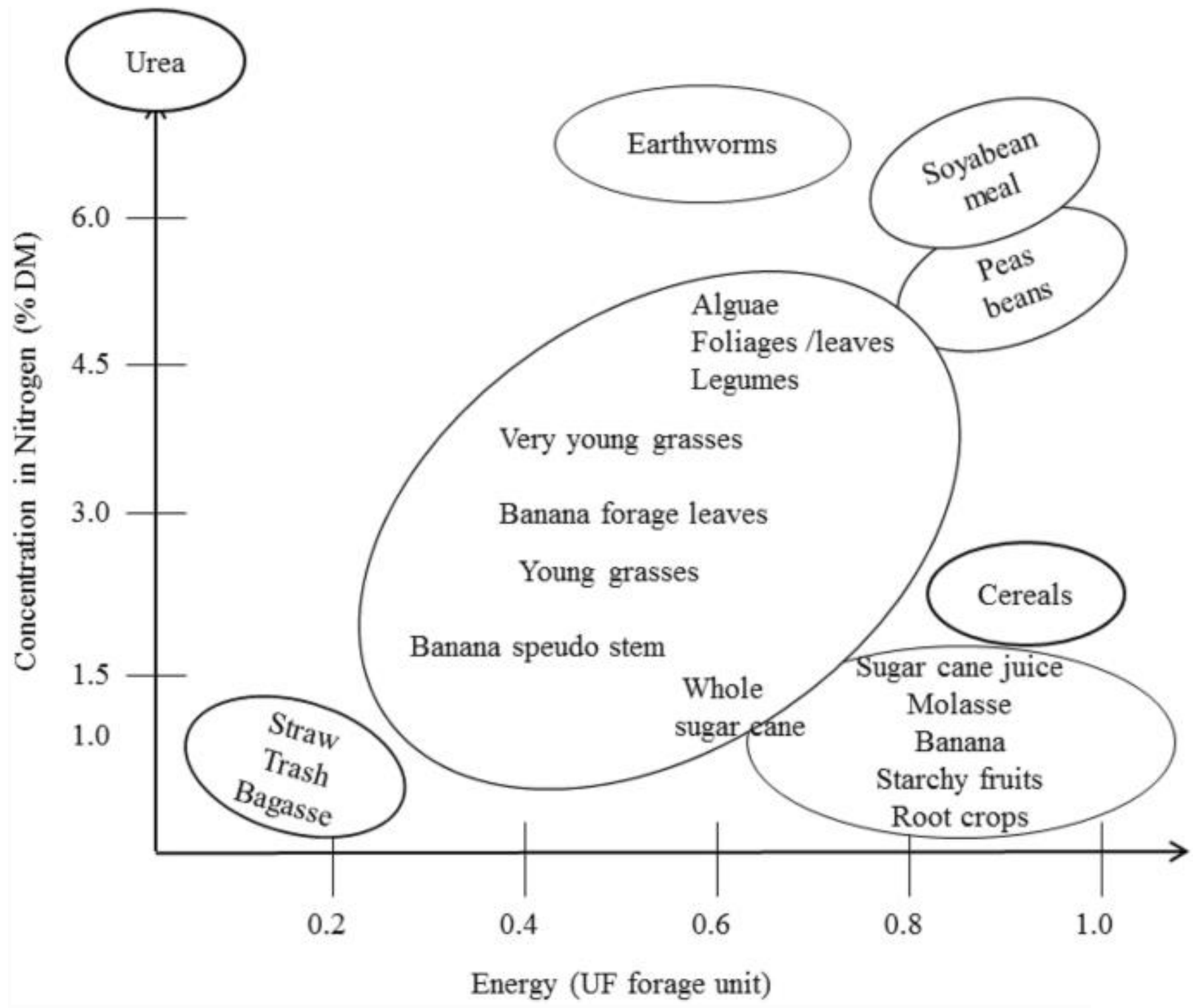

The relative value of forages, foliages, and nonconventional feeds according to energy and protein contents showing the chemical diversity (Archimède et al. 2014)

\section{Full size image}

In regions where pastoral systems remain a priority, it has been recommended that the resources should be managed through ecofriendly practices. These would include (1) using local forages (i.e., herbaceous plants or trees) adapted to drought and acidic soils (Cruz and Boval 2000; Iglesias et al. 2006; Milera 2006); (2) applying management practices better suited to their morphogenesis and/or their $\mathrm{C} 4$ physiology, leading to rapid senescence (Boval and Dixon 2012); (3) using organic fertilizers such as compost (Boval and 
Dixon 2012; Preston and Rodríguez 2014); (4) highlighting and focusing on the biological function of certain plants such as legumes and their symbiosis and ability to fixate nitrogen (Iglesias et al. 2006; Rodríguez 2010); and (5) optimizing of the use of industrial by-products (e.g., wet brewer's grains, sugar cane by-products, fruit peels, and discarded fruits or fishmeal) that are very diverse and available in large quantities in different tropical countries (González-García et al. 2012).

\section{Addressing the main environmental limits by integrated practices}

Climate mitigation

Under tropical environments, animals are generally heat-challenged. The long-term thermoregulatory reactions (Rauw et al. 2020) include a decrease in the metabolic rate (change in the distribution of adipose and muscular tissues), changes in the cardiovascular system (amplified blood circulation in heat loss organs), behavior (postures that promote heat loss through sensitive pathways, reduced intake), and general morphology (lengthening of ears and tail, naked neck) that would contribute to compensate those heat stressrelated challenges. This leads to reduced feed intake which in turn will reduce animal performance. Therefore, the feeding strategy (diet composition, feeding time as well as frequency) has been one of the principal strategies that have been prescribed to alleviate heat stress (Renaudeau et al. 2012).

Other options are possible, such as techniques to improve heat exchange between the environment and the animals. It is also a question of modifying the environment in order to anticipate or limit heat stress. Some examples are proposed. Air movement is a significant factor in the relief of heat stress, as it influences both convective and evaporative heat losses. In indoor production systems (frequently used in monogastric or dairy production), ecological ventilation rate has been amplified utilizing a well-oriented and semi-opened building. In the case of outdoor animal production, the provision of shade (i.e., ecological or artificial) has been one of the least difficult and most costeffective techniques used to limit the heat from solar radiation. Shading has been shown to be an effective method for diminishing the negative consequences and physiological impacts of heat stress on the productivity of dairy animals raised under forestry-pastoral systems in Nicaragua (Ainsworth et al. 2012). Habermeier (2003) promoted these sylvo-pastoral systems in Haiti, indicating, among other advantages of the trees (efficient biomass), that they provide beneficial cooling, as moisture evaporates from the leaves. Although there are contrasts in thermal resilience between species, there are enormous differences between breeds. An example of this has been showed 
with dairy goats reared in Trinidad and Tobago. Anglo-Nubian goats were found to be more tolerant than Saanen, resulting in higher productive levels (Lallo et al. 2012). In poultry, Creole breeds, and specifically birds with the naked neck gene, have been shown to be very well suited to tropical conditions (Almeida and Zuber 2010).

\section{Reproductive management}

Under tropical and subtropical latitudes of the Caribbean, Central, and North America, some local breeds show marked seasonal variations in sexual activity, while others show weak seasonality or a sexual activity throughout the entire year. The reproductive seasonality influences animal production significantly. The male effect (i.e., the presentation of a male into a group of anovulatory females) induces estrus and ovulation during the anestrous periods, expanding overall fertility (Delgadillo 2011). The male effect has been effectively demonstrated in local goat breeds from Guadeloupe and Mexico (Mahieu et al. 2008; Delgadillo 2011).

In subtropical Mexico, an interesting study was conducted during the night period on animals kept in open pens. In local females, the anestrous season lasts from February-March to August-September, though in males, the sexual inactive period persists from January-February to May-June. This seasonality has been for the most part affected by the photoperiod. Accordingly, photoperiod has been used to stimulate sexual activity of males during the sexual rest period: 2.5 months of artificial long days (i.e., $16 \mathrm{~h}$ of light for each day) stimulate testosterone secretion, sexual behaviors, and odor of photo-stimulated (PS) males from the end of February to the end of April.

In females, the PS males are used during the seasonal anestrous period to prompt their sexual activity. Because of the intensity of their sexual behavior, the PS males are more efficient than untreated animals in inducing and synchronizing the reproductive activity of anestrous goats in confined or grazing conditions (Delgadillo 2011, Table 2). Interestingly, the PS males can induce fertile ovulation when they are in contact with females for just $4 \mathrm{~h}$ out of each day for 15 successive days. Such males had the option to induce a high reproductive reaction in three unique groups when the time of contact between males and females was reduced to 4 hours a day (Delgadillo et al. 2014). The indirect utilization of a photoperiod to control the sexual activity of females employing photo-stimulated males is an economical strategy to control goat reproduction, as it does not use hormonal treatments. Furthermore, producers with low financial resources can use this simple and 
reasonable procedure in local livestock production systems to synchronize parturitions.

\section{Table 2 Ovulatory or estrus responses of female goats from subtropical Mexico exposed to the male effect}

\section{Full size table}

In Guadeloupe, reproduction management is intended to reach three parturitions within 2 years in Creole goats and Martinik sheep and using the male effect. The general flock productivity is hence expanded (Mahieu et al. 2008). The length of the kidding time frame is lower than 30 days in $97 \%$ of the cases, and the mating rate is accounted to be high (95\%). Prolificacy reaches 2.3 kids/goat. It is important to highlight that this reproduction management promotes productivity while protecting sustainability through ecological estrous synchronization, with no exogenous hormonal treatments.

Integrated control of parasitism constraints

The development of anthelmintic-resistant parasites has made the eradication of small ruminant gastrointestinal nematodes (GINs) unsuccessful worldwide, even with the intensive use of very efficient novel drugs. A few methodologies are being investigated in various regions such as Guadeloupe (Mahieu et al. 2009), Cuba (Arece and Rodriguez 2010), and Mexico (Hoste and TorresAcosta 2011) to tackle this issue through an integrated methodology (Mahieu et al. 2009, Fig. 3).

Fig. 3 


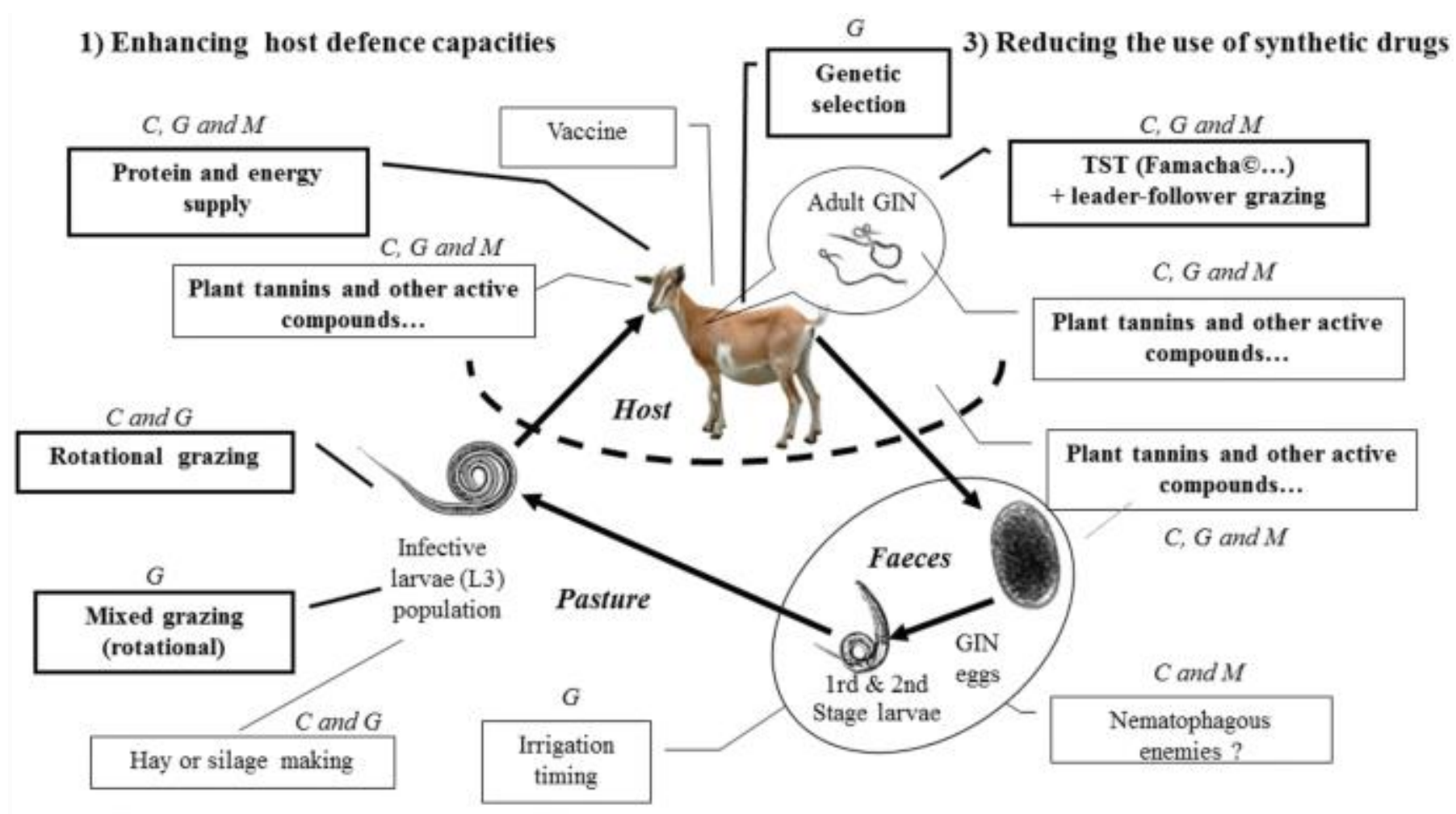

2) Decreasing the probability that GIN meet host

Integrated control of GIN in sheep or goat, concept built by Mahieu et al. (2009) and examples in Cuba (C) in Guadeloupe (G) and in Mexico (M) (in bold more promising practices)

\section{Full size image}

Firstly, it is proposed to improve host defense functions by (1) hereditary selection since the heritability of GIN infection ranged from 0.10 to 0.33 (see in Mahieu et al. 2009) or (2) providing protein and energy supply through adjusted Feeding practices (see in Mahieu et al. 2009; Torres-Acosta et al. 2012). Furthermore, it is proposed to diminish the probability that GINs meet their host, through a satisfactory field management through (1) rotational grazing system or (2) mixing species at pasture. This latter is significant as cattle are ineffectively susceptible to small ruminant GINs and vice versa. With this system, where cattle and small ruminants graze together, the degree of GIN infection and the fecal egg counts are decreased and ADG increased by 30\% when goats are mixed with cattle (Mahieu et al. 2009). Finally, a third methodology depends on the decrease of the utilization of synthetic drugs through (1) targeted specific treatment, specifically the Famacha technique (Mahieu et al. 2009; Torres-Acosta et al., 2012), generally utilized in regions where Haemonchus contortus is the predominant GIN 
species, or (2) expanded utilization of tannins or other dynamic auxiliary metabolites from plants (Marie-Magdeleine 2009; Arece et al. 2012).

Case studies in different tropical Caribbean and Latin American locations Addressing the requirements for a growing world population calls for an appreciation of the multifunctionality of agriculture and in particular of livestock production. Multifunctional agroecosystems can fulfill the multiple needs of food and fuel production and ecological and biodiversity security. These have the function of adaptation or resilience to climate change. Animals and LFS are considered as highly multifunctional in tropical agroecosystems (Dedieu et al. 2011). As opposed to the general analysis made against LFS for its negative ecological effect, our present concern is to uncover the diverse potential that exists (Fig. 1) not just for their commitment to food security (i.e., quantity and quality) but also for some different services revealed for Caribbean LFS (Alexandre et al. 2014). Overall, advancing integrated, sustainable tropical LFS requires a higher comprehension at the animal, farming, and territory levels.

\section{Case study at the animal/function level}

Multifunctional LFS are derived not only from the different objectives of the farmer (Dedieu et al. 2011) but also from the multiple physiological functions of the animal. Dual-purpose production systems represent around 80\% of the livestock utilization in Latin America. They incorporate poultry and ruminants. Dual-purpose chickens, which are generally the best decision for small farms or backyard flocks, provide both eggs and meat. Dual-purpose dairy animals produce milk and meat (calf after weaning) on each production cycle. These systems are characterized by utilizing low innovation and inadequately managed forages, which results in reduced production levels.

The animal base has been as often as possible Bos indicus and crossbreds with exotic Bos taurus breeds. Milk is utilized for farm family consumption or for sale at local markets, and calves after weaning are sold to local feedlots or export. There are opportunities to improve milk production in dual-purpose systems in the tropics by nutritional manipulation and breeding improvement. There is limited scientific information about the efficiency of the different dual-purpose breeds in using energy for maintenance and production. Along these lines, the knowledge of the partitioning of energy among milk and tissue deposition (i.e., protein, fat) in such animals and production systems has been generally lacking in the Tropics. 
Aguilar-Perez et al. (2011) demonstrated that dual-purpose dairy animals raised in Mexico utilized tropical grasses effectively for milk synthesis (regardless of whether higher milk yield was observed in the supplemented cows), recommending a redirected section of nutrients towards body maintenance and growth. Holmann (2001) made similar conclusions in Nicaragua and Honduras. In their study, Magana et al. (2010) showed that when the calf suckles the residual milk after milking, the emptying of the udder is followed by an increased milk secretion. Nevertheless, when calves suck residual milk, the fat content in machine-milked milk is decreased. Thus, machine-milked milk is less rich in fat. In some tropical zones, cows are only milked once per day, as access to the refrigeration chain is not available. This result in lower milk production contrasted with the two times per day milking in commercial small herds. On the other hand, the measure of saleable milk has been reported to be higher than that required for artificial rearing of calves. Other considerations would be the decreased rate of mastitis observed in sucked zebu crossbred cows, presumably because of improved udder emptying. Even if some other conclusions indicated that calve suckling is associated with teat damage, increased mastitis and at least shortness of the productive life of the cows. On the other hand, suckling, particularly colostrum suckling, ensures the correct passive immune transfer (i.e., immunoglobulins), which reduces morbidity and mortality in the newborn ruminants (Hernández-Castellano et al. 2018), particularly under poor hygienic conditions prevailing in extensive systems.

With respect to multipurpose animals, the other case study, on the Creole goat of Guadeloupe, underlines the diverse and intricate physiological functions that indigenous livestock demonstrate under harsh tropical conditions. The animals are raised in suckler herds and must perform the functions of reproduction, lactation, and growth. At the same time, they are confronted with climatic and pathogenic stress types and must also develop acclimatization and immunity functions. It can therefore be hypothesized that, as a result of natural selection, the gene pool of the population has become much more diverse (Alexandre et al. 2010) which has enabled them to survive and produce while dealing with many diverse and intricate constraints. This population is now under a breeding program based on a multi-criteria index combining productive and adaptive traits, whose relative economic weight has been assessed (Gunia et al. 2013). Enhancing the efficiency of multipurpose animals draws on the principles of biodiversity and avoids losing genes through selection for single purpose production.

\section{Case study at the farm/family level}


As indicated by Preston (2009), farming systems should target maximizing plant biomass production from locally accessible diversified resources, processing the biomass on the farm to provide food, feed, and energy, and recycling waste material. Preston (2009) stated that the generation of electricity can be an important by-product of food/feed production as opposed to developing biofuels, which compromise food security (see also Suárez and Martín 2012, http://www.biomascuba.ihatuey.cu/). An integrated food-feed-fuel model has been demonstrated and operationalized at the Tosoly farm (Preston and Rodríguez 2014 Fig. 4).

Fig. 4

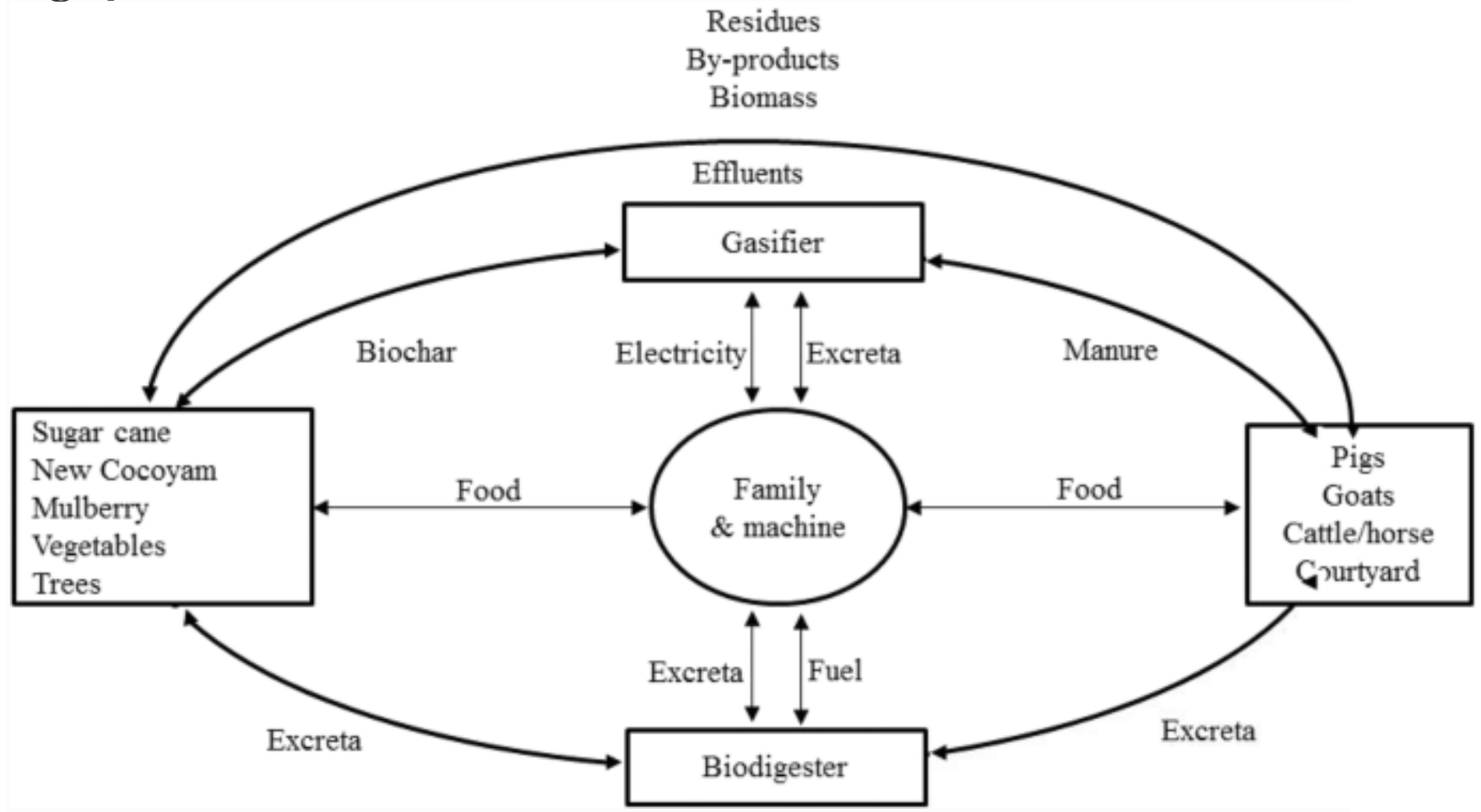

Multi-circular system of production of TOSOLY farm based upon the concept of food-feed-fuel developed and implemented by Preston and Rodríguez (2014)

\section{Full size image}

The Tosoly farm is located in a humid tropical region of Colombia and is a medium-sized family farm ( $7 \mathrm{ha}$ ). In order to promote biodiversity, the crops on the farm are replicated in different areas. The farm grows sugar cane, fruit and forage trees, and some forage plants. The livestock and fuel components are chosen for their function to use the crops and their by-products produced on the farm. This increased crop biodiversity aimed to demonstrate their dual- 
purpose and the good biomass productivity by their efficient capture of solar energy (new energy revolution) and their adequate chemical composition or nutritive value (in mixed diets).

The sugar cane is a very traditional crop spread all through the Caribbean and Latin American region. This crop could be considered as the basis of many integrated mixed farming systems (Archimède et al. 2014). Despite what might be expected, the acknowledgment of the potential role of New Cocoyam (Xanthosoma roseum) was accidental. It has been present in numerous locations in Latin America and the Caribbean. Observations on pigs fed with the leaves of New Cocoyam demonstrated that this crop is very palatable and prompted many feeding trials in Colombia and Guadeloupe (Rodríguez 2010; Archimède et al. 2014) which highlighted its suitability as a protein source.

The role of livestock in this farming system has been suggested as an approach to streamline the utilization of very productive perennial crops such as sugar cane and multipurpose trees (i.e., Cajanus cajan, Morus alba, Tithonia diversifolia). Sugar cane has been fractionated into its fiber fraction and its energy-rich juice, which can effectively replace cereal grains in feeding pigs, which has been achieved also in Cuba, Trinidad and Tobago, and Guadeloupe (Archimède et al. 2014). The residual bagasse or fiber fraction can be utilized in the gasifier. Forage trees are the natural feed resources for goats, which selectively consume the leaves, leaving the fibrous stems accessible for gasification. The nonedible cell wall biomass resulting from fractionation is the raw material that can be converted into a flammable gas by gasification. Other livestock might be included to maximize the utilization of feedstuffs, providing extra manure or draught power, and other products (i.e., eggs, rabbit meat, honey, etc.). The surplus food products can be sold in local markets. Wastewater from coffee pulping, domestic use, and all high-quality wastewater are processed through fermentation using polyethylene biodigesters (Fig. 4). Effluents from all biodigesters are collected and recycled into crops as fertilizer (even if the manure is traditionally used for compost) in a multi-circular way.

The model has been shown to be appropriate to integrate farm family systems and has spread all through some tropical countries such as Colombia and Vietnam. Clearly, not all arable land is appropriate for this integrated framework. Nevertheless, the effects from this model can be underlined through the system of LFS ecoservices. These incorporate integrated, smallscale farming systems based on multipurpose crops and livestock, providing multiple foods and feeds with no competition among these end uses. They 
have incorporated additionally the gasification of fibrous residues delivering electricity and a soil enhancer (biochar). In addition, they use gasification of fibrous residues to produce electricity and a soil improvement agent (biochar). This also provides a sink for carbon sequestration. Lastly, they incorporate the management of every liquid waste producing a gaseous fuel that can be used for cooking. The system conveys genuine advantages for the environment and the family (Fig. 4) and represents the new energy revolution suggested by Preston and Rodríguez 2014

Another example supporting the widespread interest in this food-feed-fuel model is currently being implemented in Cuba. The "Estación Experimental de Pastos y Forrajes Indio Hatuey" is conducting the BIOMAS-Cuba project in five provinces. The project concerns biodiesel production (from Jatropha curcas associated with feed resources), biogas production, and biomass gasification. This project has addressed food security, energy self-sufficiency, and environmental mitigation in the rural context. Nevertheless, the use of $J$. curcas on a large scale for the production of biodiesel may lead to significant ecological problems. These are particularly related to water use and the excessive use of pesticides and fertilizer as previously described in India (Gmünder et al. 2012), as well as the potential for competing for arable land with crops and pastures as described in Southern Africa (Gasparatos et al. 2018).

\section{Case study at the territory/society level}

In Haiti, the poorest Caribbean country and very densely populated, agriculture represents $30 \%$ of economic activities. Approximately $80 \%$ of crops and $99 \%$ of livestock come from small family farms. Many problems are caused by poor environmental conditions. Many nongovernmental organizations (NGOs) or associations have been organized under "Plateforme Agroécologique et de Développement Durable" (PADED). This is a network for agroecological practices for crop and/or livestock productions (http://www.paded.org/). They have tried to restore the production capacity through the introduction of adapted agroecological techniques in combination with economic activities. Many projects with livestock aimed to improve the soil fertility of the agroecological plots by implementing mixed crop-livestock systems (Habermeier 2003). Another livestock project is well recognized throughout the country, namely, milk production and processing. Milk is a basic product consumed by $98 \%$ of the population in Haiti. Milk imports represent more than 40 million $€$ /year. In 2005, the Veterimed NGO (Herault et al. 2010) implemented a program called "Lèt Agogo" (milk in abundance in Haitian Creole) benefiting over 250,000 small-scale poor farmers. The basis of 
the project relied on the potential for local production that could replace more than $90 \%$ of imports. With more than 450,000 cows, fewer than $20 \%$ were used for dairy production. Under such harsh conditions, cows yielded one reproductive cycle every 2 years and 5 l of milk/day during 180 days of lactation. The project demonstrated that there could be a potential for developing a local dairy sector as advocated by Hernández-Castellano et al. (2019). The program's objectives were to add value to locally produced milk and secure farmers' incomes. The NGO prescribed implementing agroecological husbandry practices such as using natural pasture and forages chosen for their productive abilities and drought tolerance, local animal genotypes with uncontrolled crossbreeding, and integrated health management. They have built water facilities in rural areas and encouraged technical training and farmer-to-farmer schools. One of their main turning points was the building of milk micro-transformation units (MMTUs), following all the regular sanitary rules with quality tests before accepting milk from farmers. So far, there were about 25 MMTUs collecting and processing milk from small farmers' unions and distributing milk products across Haiti. They have received the support of many youth and rural organizations and other PADED NGOs. "Lèt Agogo" is the brand name for those milk products (i.e., sterilized or pasteurized milk, yogurt, and cheese). "Lèt Agogo" has supplied schools through a government program. The economical income of this company has increased by three- to fourfold in 5 years, of which $30-40 \%$ has been used to promote small farmers and $17-20 \%$ to rural family workers. This case study has typified one of the main principles defended by Altieri et al. (2012), being a pro-poor project. The project has relied on participatory actions, farmer-to-farmer training, and has generated a whole milk sector to feed the Haitian population. It has increased rural household income and employments. Thus, AE can feed people and preserve the natural environment.

\section{Overview and perspectives}

The ecological processes proposed by Altieri (2002) and reformulated by Dumont et al. (2013) contribute to restore animal production in the framework of ecological reasoning. In Table 3 , the Latin American and Caribbean LFS draw attention as case studies and compared based on observations made and activities implemented. Additionally, interactions between practices are featured (Fig. 1 and Table 3 ). This helps to design integrated systems or even multi-circular economy practices. In most tropical nations, sustainable smallscale agriculture results from a synthesis of recovery and revalorization of conventional farming strategies and the innovation of new ecological 
practices. This way, the tropical LFS could offer a laboratory for additional scientific investigations. The most important are brought up in Table 3.

\section{Table 3 Livestock farming systems (LFS) in Latin America and the Caribbean, interactions between practices (1a to 2c) and comparison of the different case studies through the concept of agroecology}

\section{Full size table}

The two dimensions of LFS allow the integration of the livestock holders in the societal context to accomplish agroecological objectives as suggested by Altieri et al. (2012). Among the ecosystem services provided by tropical LFS, many are connected to socioeconomic and sociocultural dimensions of either the farmer, the family, or the overall society (Fig. 1). Many authors promoting the AE concept and practices (Habermeier 2003; Altieri et al. 2012) are interested in advancing the ethical issues related to AE. It appears important to highlight urgent items and key issues in order to help design pro-poor sustainable systems. Koohafkan et al. (2011) listed 20 questions to examine whether or not agrosystem models are contributing to sustainable livelihoods by improving capital. These questions were classified as human and social (ten questions), natural (eight questions), and financial (two questions) issues. The case studies reviewed here appear to apply to a considerable number of these items. The Colombian and Cuban cases provide some significant lessons (Funes-Monzote and Monzote 2001; Altieri et al. 2012; González-García et al. 2012). These multi-circular systems are not just restricted to traditional smallholder family farming. They show opportunities in the structure of increasingly sustainable agroecosystems at a lot more extensive scale. The instable fossil fuel prices and the numerous limitations and constraints resulting from climate changes open up an expansive range of opportunities for spreading alternative frameworks at a nation-wide scale. The Haitian case indicates likewise how a system can be genuinely pro-poor oriented.

Furthermore, a considerable number of the AE practices recommended in the present study enhance biodiversity and multiple roles for resources, animals, and systems, thus prompting improved animal production. They can be characterized as efficient as per the Funes-Monzote's classification (cited in Altieri et al. 2012). Such integrated agroecological systems additionally allow a better flexibility of tropical LFS to adapt to the major stress types (Koohafkan et al. 2011). 


\section{Conclusions}

Improving the current systems and practices is an urgent need, especially for small farmer ecological resource management models, which predominate in developing nations within the tropics.

This document showed the potential of traditional LFS or practices to contribute to the development of present-day systems that integrate agroecological principles, explicitly in the Caribbean and Latin American regions. Further research is however needed to develop innovations that will need to be adapted to tropical environments and constraints as well as socioeconomic limitations. These incorporate advancing methods at the farm level or local communities for the production of energy or nonconventional feedstuffs. Some scientific issues may be underlined for additional research, for example, inquiries of feed efficiency, nutrient partitioning, and hereditary qualities of adaptive traits and assessment of resilience.

\section{References}

1. Aguilar-Perez, FC, Ku-Vera, JC., and Magana-Monforte, JG. 2011. Energetic efficiency of milk synthesis in dual-purpose cows grazing tropical pastures, Tropical Animal Health and Production, 43, 767-772.

\section{PubMed Google Scholar}

2. Ahrens, D.C., Pellin, T. and Santoro, P.H., 2009. Agroecology at IAPAR: summaries of research projects and published works from 2004 to 2009, (Instituto Agronomico do Parana (IAPAR), Londrina, Brazil)

\section{Google Scholar}

3. Ainsworth, J.A., Moe, S.R. and Skarpe, C., 2012. Pasture shade and farm management effects on cow productivity in the tropics, Agriculture Ecosystems and Environment, 155, 105-110.

\section{Google Scholar}

4. Alexandre, G., González-García, E., Lallo, C.H.O., Ortega-Jimenez, E., Pariacote, F., Archimède, H., Mandonnet, N. and Mahieu M., 2010. Goat 
management and systems of production: global framework and study cases in the Caribbean, Small Ruminant Research, 89, 193-206.

\section{Google Scholar}

5. Alexandre, G., Mahieu, M., Mulciba, P., Kandassamy, T., Coppry, O. and Boval, M., 2012. Intérêts et limites des systèmes pâturés pour caprins en zone tropicale, Fourrages, 212, 307-317

6. Alexandre, G, Fanchone, A, Ozier-Lafontaine, H. and Diman, J.L., 2014. Livestock farming systems and agroecology in the Tropics, Sustainable Agriculture reviews, 14, 83-116.

\section{Google Scholar}

7. Almeida, A.M., 2011. The Damara in the context of Southern Africa fat tailed sheep breeds, Tropical Animal Health and Production, 43, 14271441.

\section{PubMed Google Scholar}

8. Almeida, A.M., 2018. Barbados Blackbelly: the Caribbean ovine genetic resource, Tropical Animal Health and Production, 50, 239-250.

\section{PubMed Google Scholar}

9. Almeida, A.M. and Zuber, U., 2010. The effect of the Naked Neck genotype (Nana), feeding and outdoor rearing on growth and carcass characteristics of free range broilers in a hot climate, Tropical Animal Health and Production, 42, 99-107.

\section{PubMed Google Scholar}

10.Altieri, M.A. 2002. Agroecology: the science of natural resource management for poor farmers in marginal environments, Agriculture Ecosystem and Environment, 9, 1-24.

\section{Google Scholar}


11. Altieri, M.A. and Toledo, M.V., 2011. The agro-ecological revolution in Latin America: rescuing nature, ensuring food sovereignty and empowering peasants, Journal of Peasant Studies, 38, 587-612.

\section{Google Scholar}

12.Altieri, M.A., Funes-Monzote, F.R. and Petersen, P., 2012. Agroecologically efficient agricultural systems for smallholder farmers: contributions to food sovereignty, Agronomy Sustainable Development, $32,1-13$.

\section{Google Scholar}

13. Archimède, H., Alexandre, G., Mahieu, M., Fleury, J., Petro, D., Garcia, G.W., Fanchone, A., Bambou, J.C., Marie-Magdeleine, C., Gourdine, J.L., Gonzalez, E. and Mandonnet, N., 2014. Agro-ecological resources for sustainable livestock farming in the humid tropics, Sustainable Agriculture reviews, 14, 299-330.

\section{Google Scholar}

14.Arece, J. and Rodriguez, J.G., 2010. Dynamics of gastrointestinal strongyles infesting larvae in grazing sheep, Pastos y Forrajes, 33, 99113 .

\section{Google Scholar}

15. Arece, J., Roche, Y., Lopez, Y. and Molina, M., 2012. In vitro effect of the aqueous extract of Dichrostachys cinerea (L.) Wight \& Arn. on the development of exogenous stages of gastrointestinal strongyles in sheep, Pastos y Forrajes, 35, 301-310.

\section{Google Scholar}

16. Boval, M. and Dixon, R.M., 2012. The importance of grasslands for animal production and other functions: a review on management and methodological progress in the tropics, Animal, 6, 748-762.

\section{CAS PubMed Google Scholar}


17. Cruz, P. and Boval, M., 200o. Effect of nitrogen on some morphogenetic traits of temperate and tropical perennial forage grasses. In G. Lemaire (ed), Grassland ecophysiology and grazing ecology, (CABI Publishing; Wallingford; UK), 151-168.

\section{Google Scholar}

18.de Almeida, A.M. and Cardoso, L.A., 2008. Animal production and genetic resources in Guinea Bissau: I-Northern Cacheu Province, Tropical Animal Health and Production, 40, 529-36.

\section{PubMed Google Scholar}

19. Dedieu, B., Aubin, J., Duteurtre, G., Alexandre, G., Vayssières, J., Bommel, P. and Faye, B., 2011. Conception et évaluation de systèmes d'élevage durables en régions chaudes, à l'échelle de l'exploitation, INRA Productions Animales, 24, 113-128.

\section{Google Scholar}

20. Delgadillo, J.A. 2011. Environmental and social cues can be used in combination to develop sustainable breeding techniques for goat reproduction in the subtropics, Animal, 5, 74-81.

\section{CAS PubMed Google Scholar}

21.Delgadillo, J.A., Flores, J.A., Duarte, G., Vielma, J., Hernández, H., Bedos, M., Fitz-Rodríguez, G., Fernández, I.G., López-Sebastián A., Gómez-Brunet, A., Santiago-Moreno, J., Zarazaga, L.A., Keller, M., Malpaux, B. and Chemineau, P., 2014. Out-of-season control of reproduction in subtropical goats without exogenous hormonal treatments, Small Ruminant Research, 121, 7-11.

\section{Google Scholar}

22. Devendra, C., 2007. Small farm systems to feed hungry Asia. Outlook on agriculture, 36, 720. https://doi.org/10.5367/000000007780223641 


\section{Article Google Scholar}

23. Dumont, B., Fortun-Lamothe, L., Jouven, M., Thomas, M. and Tichit, M., 2013. Prospects from agroecology and industrial ecology for animal production in the 21st century, Animal, 7, 1028-1043.

\section{CAS PubMed Google Scholar}

24. Fanchone A., Alexandre G., Chia E., Diman JL., Ozier-Lafontaine H. and Angeon V., 2020. A typology to understand the diversity of strategies of implementation of agroecological practices in the French West Indies, European Journal of Agronomy, 117, 126058

\section{Google Scholar}

25. Faye, B., Alexandre, G.. Bonnet, P., Boutonnet, J.P., Cardinale, E., Duteurtre, G., Loiseau, G., Montet, D., Mourot J. and Regina F., 2011. Elevage, qualité des produits en régions chaudes, INRA Prod. Anim., 24, 77-88.

\section{Google Scholar}

26. Friggens, N.C. and Newbold J.R., 2007. Towards a biological basis for predicting nutrient partitioning: the dairy cow as an example, Animal, 1, 87-97.

\section{CAS PubMed Google Scholar}

27.Funes-Monzote, F. and Monzote, M., 2001. Integrated agro-ecological systems as a way forward for Cuban agriculture. Livestock Research for Rural Development. Retrieved on 26 September 2013 from http://www.lrrd.org/lrrd13/1/fune131.htm

28. Gasparatos, A., von Maltitz, G.P., Johnson, FX., Romeu-Dalmau, C., Jumbe, CBL., Ochieng, C., Mudombi, S., Balde, BS., Luhanga, D., Lopes P., Nyambane, A., Jarzebski, MP and Willis, KJ., 2018. Survey of local impacts of biofuel crop production and adoption of ethanol stoves in southern Africa, Science Data, 5, 180-186.

\section{Google Scholar}


29. Gliessman, S.R., 2006. Animals in agroecosystems, In Agroecology: the ecology of sustainable food systems. (CRC Press, Boca Raton, FL, USA)

\section{Google Scholar}

30. Gmünder, S., Singh, R., Pfister, S., Adheloya, A. and Zah, R., 2012. Environmental impacts of Jatropha curcas biodiesel in India, Journal of Biomedecine and Biotechnology, doi: 101155/2012/623070, Retrieved on 16 March 2015 http://www.ncbi.nlm.nih.gov/pubmed/22919274

31. González-García, E., Gourdine, J.L., Alexandre, G., Archimède, H. and Vaarst, M., 2012. The complex nature of mixed farming systems requires multidimensional actions supported by integrative research and development efforts, Animal, 6, 763-777.

\section{PubMed Google Scholar}

32. Gourdine, J.L., Renaudeau, D., Riquet, J., Bidanel, J.P. and Gilbert, H., 2013. Breeding pigs for heat tolerance: challenges to face. Proceedings of the $64^{\text {th }}$ Annual Meeting of the European Federation of Animal Science, Nantes, France, 2013, 133-134.

33. Gourdine, J.L., Riquet, J., Rose, R., Poullet, N., Giorgi, M., Billon, Y., Renaudeau, D. and Gilbert, H., 2019. Genotype by environment interactions for performance and thermoregulation responses in growing pigs. Journal of Animal Science, 97, 36993713. https://doi.org/10.1093/jas/skz245

\section{Article PubMed PubMed Central Google Scholar}

34. Gunia, M., Mandonnet, N., Arquet, R., Alexandre, G., Gourdine, J.L., Naves, M., Angeon, V. and Phocas, F., 2013. Economic values of body weight, reproduction and parasite resistance traits for a Creole goat breeding goal, Animal, 7, 22-33.

\section{CAS PubMed Google Scholar}

35. Habermeier, K., 2003. Jaden agroforestyé se jaden abondans, PADED-Misereor, Port-au-Prince, Haiti. 
36. Herault, M., Moise, R. and Chancy, M., 2010. Milk production in small farms in Haiti: "Lèt agogo" (milk in abundance) experience, Advances in Animal Biosciences 1, 494-495.

\section{Google Scholar}

37.Hernández-Castellano, L.E., Özçelik, R., Hernandez, L.L. and Bruckmaier, R.M., 2018. Supplementation of colostrum and milk with 5-hydroxy-l-tryptophan affects immune factors but not growth performance in newborn calves, Journal of Dairy Science, 101, 794-800.

\section{PubMed Google Scholar}

38. Hernández-Castellano, L.E., Nally, J.E., Lindahl, J., Wanapat, M., Alhidary, I.A., Fangueiro, D., Grace, D., Ratto, M., Bambou, J.C. and de Almeida, A.M., 2019. Dairy science and health in the tropics: challenges and opportunities for the next decades, Tropical Animal Health and Production, 51, 1009-1017.

\section{PubMed Google Scholar}

39. Hoffmann, I., 2013. Adaptation to climate change - exploring the potential of locally adapted breeds, Animal, 7, 346-362.

\section{PubMed Google Scholar}

40. Holmann, F., 2001. Milk market of small scale artisan cheese factories in selected livestock watersheds of Honduras and Nicaragua. Retrieved on 26 September 2013 from http://www.lrrd.org//rrd13/1/holm131.htm

41. Hoste, H. and Torres-Acosta, J.F.J., 2011. Non chemical control of helminths in ruminants: Adapting solutions for changing worms in a changing world, Veterinary Parasitology, 180, 144-154.

\section{CAS PubMed Google Scholar}

42. Iglesias, J.M., Simon, L., Lamela, L., Hernandez, D., Milera, M., Castillo, E. and Sanchez, T., 2006. Agroforestry systems in Cuba: some aspects of animal production, Pastos y Forrajes, 29, 217-235. 


\section{Google Scholar}

43. Koohafkan, P, Altieri, M.A., and Gimenez, E.H., 2011. Green agriculture: foundations for biodiverse, resilient and productive agricultural systems, International Journal of Agricultural Sustainability, 10, 61-75.

\section{Google Scholar}

44. Lallo, C.H.O., Paul, I. and Bourne, G., 2012. Thermoregulation and performance of British Anglo-Nubian and Saanen goats reared in an intensive system in Trinidad, Tropical Animal Health and Production, 44, 491-496.

\section{PubMed Google Scholar}

45. Lérias, J.R., Hernández-Castellano, L.E., Morales-delaNuez, A., Araújo, S.S., Castro, N., Argüello, A., Capote, J. and deAlmeida, A.M., 2013. Body live weight and milk production parameters in the Majorera and Palmera goat breeds from the Canary Islands: influence of weight loss, Tropical Animal Health and Production, 45, 1731-1736.

\section{PubMed Google Scholar}

46. Magana, J.G., Parra-Bracamonte, G.M. and Estrada-Leon, R.J., 2010. Characterization of animal genetic resource in the design of sustainable cattle production systems in the tropics, Tropical and Subtropical Agro-ecosystems, 10, 85-94.

\section{Google Scholar}

47. Mahieu, M., Archimède, H., Fleury, J., Mandonnet, N. and Alexandre, G., 2008. Intensive grazing system for small ruminants in the Tropics: The French West Indies experience and perspectives, Small Ruminant Research, 77, 195-207.

\section{Google Scholar}

48. Mahieu, M., Arquet, R., Fleury, J., Coppry, O., Marie-Magdeleine, C, Boval, M, Archimède, H., Alexandre, G., Bambou, J.C. and Mandonnet N., 2009. Contrôle intégré du parasitisme gastro-intestinal 
des petits ruminants au pâturage en zone tropicale humide, Rencontres autour des Recherches sur les Ruminants 16, 265-268.

\section{Google Scholar}

49. Marie-Magdeleine, $\mathrm{C}$, 2009. Etude de ressources végétales tropicales pour un usage anthelminthique en élevage de ruminants. (Phd thesis, Université des Antilles Guyane, Guadeloupe).

50. Martínez, AM., Gama, LT, Cañón, J., Ginja, C, Delgado, JV., Dunner, S., Landi, V., Martín-Burriel, I., Penedo, MC., Rodellar, C., Vega-Pla, JL., Acosta, A., Alvarez, LA., Camacho, E., Cortés, O., Marques, JR., Martínez, R., Martínez, RD., Melucci, L., MartínezVelázquez, G., Muñoz, JE., Postiglioni, A., Quiroz, J., Sponenberg, P., Uffo, O., Villalobos, A., Zambrano, D. and Zaragoza, P., 2012. Genetic footprints of Iberian cattle in America 500 years after the arrival of Columbus, PLoS One, 7(11):e49066. https://doi.org/10.1371/journal.pone.0049066. Epub 2012 Nov 14.

\section{CAS Article PubMed PubMed Central Google Scholar}

51. Milera, M., 2006. Milk production systems from forage herbaceous and tree resources, Pastos y Forrajes, 29, 109-134.

\section{Google Scholar}

52. Naves, M., Alexandre, G., Leimbacher, F., Mandonnet, N. and Menendez-Buxadera, A., 2000. Le point sur les programmes de gestion des ressources génétiques chez les espèces de ruminants dans la Caraïbe, INRA Productions Animales, 14,182-192.

\section{Google Scholar}

53. Palma M., Alves, S.P., Hernández-Castellano, L.E., Capote, J., Castro, N., Argüello, A., Matzapetakis, M., Bessa, R.J.B. and deAlmeida, A.M., 2017. Mammary gland and milk fatty acid composition of two dairy goat breeds under feed-restriction, Journal of Dairy Research, 84, 264-271.

\section{CAS Google Scholar}


54. Poullet, N., Bambou, J.C., Loyau, T., Trefeu, C., Feuillet, D., Beramice, D., Bocage, B., Renaudeau, D. and Gourdine, J.L., 2019. Effect of feed restriction and refeeding on performance and metabolism of European and Caribbean growing pigs in a tropical climate, Scientific Reports, 9. https://doi.org/10.1038/s41598-019-41145-w

55.Preston, R., 2009. Sustainable production of food, feed and fuel from natural resources in the tropics, Tropical Animal Health and Production, 41, 1071-1080.

\section{PubMed Google Scholar}

56. Preston, R. and Rodríguez, L. 2014. Production of food and energy from biomass in an integrated farming system, experiences from the TOSOLY farm in Colombia, Sustainable Agriculture Reviews, 14, 23-51.

\section{Google Scholar}

57.Rauw, W.M., Rydhmer, L., Kyriazakis, I., Overland, M., Gilbert, H., Dekkers, J.C.M., Hermesch, S., Bouquet, A., Izquierdo, E.G., Louveau, I. and Gomez-Raya, L., 2020. Prospects for sustainability of pig production in relation to climate change and novel feed resources, Journal of the Science of Food and Agriculture, 100, 35753586. https://doi.org/10.1002/jsfa.10338

\section{CAS Article PubMed PubMed Central Google Scholar}

58. Renaudeau, D., Collin, A., Yahav, S., de Basilio, V., Gourdine, J.L. and Collier, R.J., 2012. Adaptation to hot climate and strategies to alleviate heat stress in livestock production, Animal, 6, 707-728.

\section{CAS PubMed Google Scholar}

59. Rodríguez, L. 2010. Integrated farming systems for food and energy in a warming, resource-declining World. Thesis of Humboldt University, Berlin towards the Degree of Doctor of Philosophy.

6o. Scanlon, T.T., Almeida, A.M., van Burgel, A., Kilminster, T., Milton, J., Greeff, J.C. and Oldham, C., 2013. Live weight parameters in Dorper, Damara and Australian Merino lambs subjected to restricted feeding, Small Ruminant Research, 109, 101-106. 


\section{Google Scholar}

61. Suárez, J. and Martín, G.J., 2012. La biomasa como fuente renovable de energía en el medio rural: La experiencia del proyecto internacional BIOMAS-CUBA, (Estación Experimental "Indio Hatuey”, Matanzas, Cuba)

\section{Google Scholar}

62. Torres-Acosta, JFJ., Sandoval-Castro, CA., Hoste, H., AguilarCaballero, AJ., Cámara-Sarmiento, R. and Alonso-Díaz, MA., 2012. Nutritional manipulation of sheep and goats for the control of gastrointestinal nematodes under hot humid and subhumid tropical conditions, Small Ruminant Research 103, 28- 40.

\section{Google Scholar}

63. Wezel, A., Bellon, S., Dore, T., Francis, C., Vallod, D. and David, C., 2009. Agroecology as a science, a movement and a practice. A review, Agronomy Sustainable Development, 29, 503-515.

\section{Google Scholar}

64. Wilson, T.R., 2009. Fit for purpose - the right animal in the right place, Tropical Animal Health and Production, 41, 1081-1090.

\section{PubMed Google Scholar}

Download references

\section{Acknowledgments}

This study was supported by the European community and Region Guadeloupe within the AgroEcoDiv project.

The anonymous reviewer is thanked for his very constructive comments and suggestions which improved the paper.

\section{Author information}


Affiliations

1. INRA, UR143, Unité de Recherches Zootechniques, 97170 Petit-Bourg, Guadeloupe, French West Indies, France Gisele Alexandre, Audrey Fanchone, Jean-Luc Gourdine \& Harry Archimède

2. Finca TOSOLY, AP 23, Socorro, Colombia Lylian Rodriguez

3. Estación Experimental de Pastos y Forrajes "Indio Hatuey", Universidad de Matanzas "Camilo Cienfuegos", CP 44280, Matanzas, Cuba Javier Arece

4. Centro de Investigación en Reproducción Caprina, Universidad Autónoma Agraria Antonio Narro, C.P. 27054, Torreón, Coahuila, Mexico José Delgadillo

5. The Open Tropical Forage-Animal Production Laboratory, Department of Food Production, Faculty of Food and Agriculture, The University of the West Indies, St. Augustine Campus, St. Augustine Campus, Trinidad and Tobago Gary Wayne Garcia

6. Plateforme d'Agroécologie et de Développement Durable (PADED)-Misereor, 10, impasse Basilic, Delmas 65, Haiti Kurt Habermeier

7. LEAF, Instituto Superior de Agronomia, University of Lisbon, Tapada da Ajuda, Lisbon, Portugal

André M. Almeida

Corresponding author

Correspondence to Gisele Alexandre.

Ethics declarations

The authors declare that the manuscript complies with the Ethical Rules applicable for Tropical Animal Health and Production journal.

Conflict of interest

The authors declare they have no conflict of interest. 